\title{
Human Rights for Indigenous Peoples
}

\author{
Felix Dalimartha ${ }^{1}$, Rieneke Sara ${ }^{2}$ \\ Universitas Borobudur Jakarta ${ }^{1,2}$ \\ \{felixunbor@gmail.com ${ }^{1}$, rineke_sara@borobudur.ac.id ${ }^{2}$ \}
}

\begin{abstract}
Indigenous peoples are part of a group that is vulnerable to violations of human rights. The violations that occur are caused by this vulnerable group that cannot defend itself without other parties' help. By using normative juridical research methods, it is found that indigenous peoples are part of the Indonesian people who have the same rights in the eyes of the state. Population rights, rights of religion and belief as well as land rights are rights that must be protected by the State of Indonesia. Indigenous peoples who are vulnerable to discrimination require legal protection and legal guarantees from the State of Indonesia. Human rights are part of the right to life and need to be upheld in Indonesia. Indigenous peoples are part of what must be protected by the state in upholding human rights.
\end{abstract}

Keywords: Indigenous people; Human Rights; Legal Protection

\section{Introduction}

Various efforts aimed at protecting and advancing Human Rights (HAM) in Indonesia are very strategic matters that require the attention of all elements of the nation. In the 1999-2004 State Policy Outlines stipulated that one of the missions of national development is to place human rights and the rule of law as a development sector that receives special attention. For this purpose, it is necessary to establish a national legal system that guarantees the upholding of the rule of law and human rights-based on justice and truth.

The State obligations regarding human rights internationally are regulated in various international human rights law instruments, including, such as in the UDHR, ICCPR and as previously mentioned, the Convention Against Torture (CAT). At the national level, the state's obligations regarding human rights are regulated in national laws and regulations, for example in the constitution and laws.

Concretely, the state's obligations regarding human rights are realized by protecting the human rights of each individual from abuse of state power, ensuring the existence of human rights of every individual in the provisions of law and its implementation, and fulfilling the human rights of every individual. For example, regarding the right not to be tortured, the state must make legal regulations that prohibit the practices of torture to protect every individual from acts of torture. The State must also ensure that every individual should be completely free from torture, and it's must fulfill the right not to be tortured in real terms.

By law, the state is the party that must protect, ensure, and fulfills human rights. Why is that? Because the state is the party that has the power. Concerning human rights, the state is demanded not to abuse its power. The definition of a state here includes not only the 
government (executive) but also the legislature and the judiciary. This includes all state officials/law enforcement officers.[1]

According to Article 8 of Law Number 39 of 1999 concerning Human Rights, protection, promotion, enforcement, and fulfillment of human rights is the responsibility of the government as well as the community. The government has issued various laws and regulations and ratified various conventions, such as the convention on the rights of the child, the convention on the elimination of all forms of discrimination against women and others, but it has not been supported by a strong joint commitment to implement these instruments. Based on this situation, it is necessary to develop an effective law enforcement mechanism to protect the rights of citizens, especially the rights of vulnerable groups.[2]

The meaning of Vulnerable Groups is not formulated explicitly in statutory regulations, as stated in Article 5 paragraph (3) of Law No.39 of 1999 which states that everyone belonging to vulnerable groups of people has the right to receive treatment and protection concerning their specificity. In the elucidation of the article, it is stated that what is meant by vulnerable groups of people, among others, are the elderly, children, the poor, pregnant women, and people with disabilities. Meanwhile, according to Human Rights Reference [3] stated that those classified as Vulnerable Groups are: a. Refugees, b, Internally Displaced Persons (IDPs); c. National Minorities, d. Migrant Workers; e. Indigenous Peoples, f. Children; and g. Women.

Indigenous peoples are part of a group that is vulnerable to violations of human rights. The violations that occur are caused because this vulnerable group cannot defend itself without other parties' help. This ability can be the result of domination or pressure from the majority of groups or other parties. The majority of indigenous people live in the outermost areas, so they are far from the crowds and reach of the general public. Its unfavorable geographic location has made its existence often marginalized when dealing with other communities, especially entrepreneurs who want to open new land and expand new land. Indigenous peoples' human rights are often marginalized, especially in terms of their rights to education, health, and customary rights. This paper intends to discuss how to protect human rights for indigenous peoples.

\section{Method}

This research uses juridical normative, which is legal research, based only on secondary data in the form of laws and regulations and other library materials related to recognition and customary law communities, and are analyzed by legal reasoning including interpretation, systematization, and evaluation of regulations. rule of law, which refers to positivity (certainty), coherence, and justice.[4]

\section{Content and Discussion}

The problem faced in various regions of Indonesia is that there is still a lot of discrimination against minority groups, both ethnic and religious, even though they as a society or ethnic group must be treated the same as other majority groups. In the context of promoting and protecting minorities, such as the prohibition of discrimination because discrimination harms minorities politically, socially, culturally, and economically and is a major source of tension.[5] Discrimination means showing any difference, exclusion, limitation, or privilege based on reasons such as race, color, language, religion or national or 
social origin, birth status, or another status, which has the purpose or influence of negating or undermining recognition, enjoyment, fulfillment of all equal rights and freedoms of all.

Important protection signs that will benefit minorities include recognition as individuals before the law, equality before judicial bodies, equality before the law, equal legal protection in addition to important rights such as freedom of religion, expression, and association. In this connection, various laws and regulations have been implemented as national human rights and legal instruments in addition to international human rights instruments, such as: (a) the 1965 International Covenant on the Elimination of All Forms of Racial Discrimination (Article 1); (b) UNESCO Declaration on Race and Racial Prejudice 1978 (Articles 1, 2 and 3); and (c) the 1981 Declaration on the Based of Religion and Belief (Article 2).[6]

Explanation of the general provisions of the Human Rights Law No.39 of 1999, discrimination is a limitation, harassment, or exclusion that is directly or indirectly based on human differences based on religion, ethnicity, race, group, class, social status, economic status, gender, language which results in a decrease, deviation or elimination of recognition, implementation of human rights and basic freedoms in life, both individually and collectively in the economic, social, cultural and other aspects of life.[7] Normatively, the form of legal protection has been regulated through international and national instruments related to human rights against minority groups, but in implementation, it is still deemed necessary to become a common concern. It is including the patterns of interaction between minority groups and other groups to be carried out properly based on the principles of openness and tolerance towards the values of all groups in society.

Human rights are naturally inherent in every human being since he was born into the world. By nature, among others, humans have the right to freedom. Rosevelt argues that in living in society and as a state, humans have The Four Freedoms[1] , namely:

a. Freedom of Speech;

b. Freedom of Religie;

c. Freedom from Fear;

d. Freedom from Want.

The foundation of our country, Pancasila, contains the idea that humans were created by God Almighty which carries two aspects, namely the individualist (personal) aspect, and the socialist (social) aspect. Therefore, the freedom of everyone is limited by the human rights of others. It means that everyone must recognize and respect the human rights of others. This obligation also applies to every organization at any level, especially the State and the Government. Thus the state and government are responsible for respecting, protecting, defending, and guaranteeing the rights of every citizen and population without discrimination.

Discriminatory action occurs when there is restrictions, harassment, or exclusion that directly or indirectly differentiates humans based on religion, ethnicity, race, ethnicity, group, class, social status, economic status, gender, language, political beliefs; which results in reducing/eliminating the recognition of human rights and basic freedoms in life both individually and in groups in the political, economic, legal, social, cultural and other aspects of life. Various human rights in various aspects of life can be explained as follows:

a. Political rights, namely the right to participate in government, the right to vote and be elected in elections, the right to establish a party, and so on.

b. Economic human rights (property right), the right to own something, buy and sell it, and take the benefit of it.

c. Legal human rights (right of legal equality), namely the right to receive equal treatment in law and government. As well as the right to receive equal treatment in judicial 
procedures and protection (procedural right). For example regulations in, arrest, search, trial, and so on.

d. Social and cultural rights, for example, the right to choose education, develop culture, etc.

e. Personal right, which includes freedom of expression, freedom to embrace religion, etc.

The discrimination acts mentioned above constitutes human rights violations, both vertically (committed by state officials against citizens or vice versa), or horizontally (among citizens themselves); and not a few are included in the category of gross violations of human rights. What is meant by gross human rights violations includes: [8] :

a. Mass murder (genocide)

b. Arbitrary/extrajudicial killing

c. Torture

d. Enforced disappearances

e. Slavery

f. Systematic discrimination

Conceptually it can be argued that what is meant by "Human Rights Violation" is: Every act of a person/group, whether intentional/unintentional/negligent against the law reduces/hinders/limits the human rights of a person or group guaranteed by law, it is feared that they will not get a fair and correct based on the applicable legal mechanism.[9]

One of the concrete examples of discriminatory treatment experienced by the general public against members of indigenous peoples is the treatment of members of indigenous people who attend public schools. These indigenous community members are discriminated against because of the difference from the general public. These differences can be seen in religion, belief, and identity. As a result of different beliefs from the general public, it becomes a trigger to be treated in a discriminatory manner.

Those discriminatory treatment is not only about the identity of the belief, but also regarding the factor of traditional marriage which is believed and carried out by the indigenous community. Traditional marriages done by indigenous people are often not recognized by state institutions and are considered illegal marriages because they are not registered by the state. Indigenous marriages that are not recognized by the state result in a birth certificate for the child born from the marriage. Children's birth certificates that cannot be processed cause the formal education process to be hampered. This discrimination results in the level of education in indigenous people is very low.

Another discrimination occurs in terms of legal rights when dealing with entrepreneurs who want to clear land in customary territories. The expanse of new land has become a polemic among indigenous people. Customary land rights or Ulayat rights are often overridden by the state when dealing with state-legal processes. Discrimination related to legal rights and land rights is a separate phase of discrimination experienced by indigenous peoples in the sights of the law. This is often becoming a dispute between indigenous people and the public society.

When linked to human rights, then the state should protect indigenous people's human rights. Indigenous people are part of the Indonesian people who have the same rights in the eyes of the state. Population rights, rights of religion and belief as well as land rights are the rights that must be protected by the State of Indonesia. Indigenous people who are vulnerable to discrimination need legal protection and legal guarantees from the State of Indonesia. Human rights are part of the right to life and require to be upheld in Indonesia. Indigenous people are part of what must be protected by the state in upholding human rights. 


\section{Conclusion}

Human rights are naturally inherent in every human being since he was born into the world. Indigenous people are part of a group that is vulnerable to violations of human rights. The violations that occur are caused by this vulnerable group that cannot defend itself without assistance from other parties. This ability can be the result of domination or pressure from the majority of groups or other parties. The majority of indigenous people live in the outermost areas, far from the crowds and reach of the general public. Its unfavorable geographic location has made its existence often marginalized when dealing with other communities, especially entrepreneurs who want to open and expand new land. The human rights of indigenous people are often marginalized, especially in terms of their rights toward education, health, and customary rights. Indigenous people who are vulnerable to discrimination need legal protection and legal guarantees from the State of Indonesia. Human rights are part of the right to life and need to be upheld in Indonesia. Indigenous people are part of what must be protected by the state in upholding human rights.

\section{Reference}

[1] Romli Atmasasmitha, "International Criminal Law and the Law of Human Rights," 2005.

[2] M. Muhammad, "Hak Asasi Manusia Dalam Hukum Positif Dengan Konsep Constitutional Importance," Meraja J., vol. 1, no. 2, pp. 31-39, 2018, [Online]. Available: http://merajajournal.merajamedia.com/index.php/mrj/article/view/17.

[3] W. van G. J.M, Human Rights Reference. The Hague: Netherlands ministry of foreign Affairs, 1994.

[4] I. M. P. Diantha, "Metodologi Penelitian Hukum Normatif," Teor. Metodol. Penelit. a., 2017.

[5] I. Hoesin, "Perlindungan terhadap kelompok rentan (wanita, anak, minoritas, suku terasing, dll) dalam perspektif hak asasi manusia," Semin. Pembang. Huk. Nas. ke VIII tahun 2003, 2003.

[6] S. Handajani, "HUKUM, DEMOKRASI DAN HAK ASASI MANUSIA: MAKNA DAN IMPLEMENTASINYA DI INDONESIA,” Perspektif, vol. 6, no. 4, p. 305, Oct. 2006, doi: 10.30742/perspektif.v6i4.537.

[7] I. Kusumawardhana and R. J. Abbas, "Indonesia di Persimpangan: Urgensi 'UndangUndang Kesetaraan dan Keadilan Gender' di Indonesia Pasca Deklarasi Bersama Buenos Aires Pada Tahun 2017," J. HAM, vol. 9, no. 2, p. 153, Dec. 2018, doi: 10.30641/ham.2018.9.153-174.

[8] Komisi Nasional Hak Asasi Manusia, "PEMETAAN HAK ATAS KEBEBASAN BERAGAMA DAN KEPERCAYAAN DI ENAM DAERAH,” 2009.

[9] N. Atqiya, "HAM DALAM PERSPEKTIF ISLAM," Islam. J. Stud. Islam, vol. 1, no. 2, Oct. 2014, doi: 10.19105/islamuna.v1i2.565. 